\title{
ANTIOXIDANT ACTIVITY OF RED DRAGON FRUIT PEEL (HYLOCEREUS POLYRHIZUS (F.A.C. WEBER) BRITTON AND ROSE) ISOLATES USING 2,2-DIPHENYL-1-PICRYLHYDRAZYL METHOD
}

\author{
SRI WAHDANINGSIH ${ }^{1,2 *}$, SUBAGUS WAHYUONO², SUGENG RIYANTO ${ }^{2}$, RETNO MURWANTI ${ }^{2}$ \\ ${ }^{1}$ Departement of Pharmacy, Faculty of Medicine, Tanjungpura University, Pontianak, Indonesian. ${ }^{2}$ Faculty of Pharmacy, Gadjah Mada \\ University, Indonesia. Email: wahdanieanie@gmail.com
}

Received: 22 July 2017, Revised and Accepted: 03 October 2017

\section{ABSTRACT}

Objective: Indonesia is a country which has various natural resources including medicinal plants. Among the plants, red dragon fruit is interesting to be studied. In this study, antioxidant activity of red dragon fruit peel (Hylocereus polyrhizus (F.A.C. Weber) Britton and Rose) isolate was tested using 2,2-diphenyl-1-picrylhydrazyl method.

Methods: Isolation of active compounds was performed through the application of vacuum liquid chromatography and preparative thin-layer chromatography (TLC). Antioxidant activity was tested using both TLC and spectrophotometry.

Result: Results revealed that the values of $\mathrm{IC}_{50}$ of isolate 1 and 2 were $2.952,14 \mu \mathrm{g} / \mathrm{mL}$ and $25.635,95 \mu \mathrm{g} / \mathrm{mL}$, respectively.

Conclusion: Isolate of dragon fruit has antioxidant activity. The compound which results in antioxidant activity is terpenoid and steroid.

Keywords: Red dragon fruit peel, Isolate, Antioxidant, 2,2-diphenyl-1-picrylhydrazyl.

(C) 2018 The Authors. Published by Innovare Academic Sciences Pvt Ltd. This is an open access article under the CC BY license (http://creativecommons. org/licenses/by/4. 0/) DOI: http://dx.doi.org/10.22159/ajpcr.2018.v11i1.21519

\section{INTRODUCTION}

Indonesia is a country which has various natural resources including medicinal plants which can be used in phytotherapy. Among the plants, red dragon fruit is interesting to be studied. Dragon fruit is a tropical fruit containing polyphenol, antioxidant, and high fiber [1]. The improving rate of consumption of the fruit leads to the large amount of left peel. The fruit peel weighs about $22 \%$ of its total weight; it has not been used optimally so that it causes pollution [2]. According to the acetone extract, dragon fruit peel has $118 \pm 4.12$ of $\mathrm{EC}_{50}$ value, with $8.33 \pm 0.11 \mathrm{mg}$ catechin equivalent of total flavonoid content. The total phenolic content is $39.7 \pm 5.39 \mathrm{mg} \mathrm{GAE} / 100 \mathrm{~g}$ wet weight. The content of betacyanin, a color pigment having antioxidant activity, is $10.3 \pm 0.22$ and $13.8 \pm 0.85 \mathrm{mg}$ betanin equivalent per $100 \mathrm{~g}$ fresh pulp and peel [3]. Nurliyana et al. stated that $1 \mathrm{mg} / \mathrm{ml}$ red dragon fruit peel can inhibit $83.48 \pm 1.02 \%$ free radical 2,2-diphenyl-1-picrylhydrazyl (DPPH) [4]. The activities of antioxidant of methanol extract, ethyl acetate soluble fraction, and ethyl acetate insoluble fraction are $241.19 \mu \mathrm{g} / \mathrm{mL}, 8.34 \mu \mathrm{g} / \mathrm{mL}$, and $46.84 \mu \mathrm{g} / \mathrm{mL}$, respectively [5]. Free radical is a molecule having an unpaired valence electron, so it is very reactive. In high concentration, free radical can result in oxidative stress leading to damaged cell structures, including damage to lipids, proteins, and DNA. The existence of free radicals in body can cause chronic and degenerative diseases [6]. Free radicals can be countered with antioxidant. Based on the sources, there are two kinds of antioxidant which are synthetic and natural. Considering the side effects of synthetic antioxidants such as hepatomegaly and carcinogenic, natural antioxidants become chosen alternative [7]. Much research has aimed to counterbalance the adverse effects of free radicals by complementing the endogenous antioxidant defense system with medicinal plants. Free radicals are known to play a definite role in a wide variety of pathological symptoms. Natural antioxidants offer a wide range of biochemical entities, including inhibition of reactive oxygen species generation, direct or indirect scavenging of free radicals, and alteration of intracellular redox potential $[8,9]$. The objective of this study was to explore the compounds of red dragon fruit peel which has the capacity to be a scavenger of free radicals DPPH.

\section{RESEARCH METHOD}

Tools and materials

Material

The main material used in this study was the peel of red dragon fruit (Hylocereus polyrhizus) obtained from Bantul, Yogyakarta, Indonesia. The solvents used were methanol, ethyl acetate, petroleum ether, and pro analysis quality chloroform (Merck), Vitamin C, and DPPH [Sigma]. The reagents were cerium sulfate and silica gel 60 for column chromatography, silica gel $\mathrm{PF}_{254^{*}}$

\section{Sample preparation}

About $500 \mathrm{~g}$ of peel powder were macerated using methanol; some mixings were performed, and the filtrate was evaporated using rotary evaporator to produce the condensed extract. The extract was then partitioned using $50 \mathrm{ml}$ petroleum ether. The partition was performed several times to get clear fractions of petroleum ether. The soluble and insoluble fractions were evaporated to make them condensed.

Fractionation using vacuum liquid chromatography [VLC] column The stage of VLC involved: About $2 \mathrm{~g}$ of extract were diluted using a proper solvent in a porcelain saucer and then dried using silica gel to get dry powder. Sinterglass was filled with static phase powder silica gel 60 for column chromatography until it reached $\pm 1 / 2$ of its height; the sample of the powder was put on it and was covered with filter paper. Then, elution by vacuum using mobile phases, petroleum ether, and ethyl acetate was performed.

a. Testing of target compounds

Test of antioxidant activity was performed both qualitatively and quantitatively. The qualitative testing used a specific reagent that was DPPH of thin-layer chromatography (TLC) fraction result. The diluted compounds were sprayed with $0.02 \% \mathrm{~b} / \mathrm{v}$ DPPH spot appearance. The spot scavenging free radicals showed yellow color with purple background in $30 \mathrm{~min}$ or less. The antioxidant activity of DPPH free radicals was quantitatively tested using spectrophotometry ultraviolet (UV)-visible. 
b. Preparative TLC

Active compounds of fraction were isolated using preparative with static phase silica gel $\mathrm{PF}_{255}, 0.5 \mathrm{~mm}$ of thickness. The compound solution was spotted to a long ribbon-shaped plate. Then, the plate was put into a vessel containing promoter solution. When the development was completed, the plate was removed from the vessel and was dried until the phase evaporated. To find the spots of the ribbon to be scrapped, the edges of the plate were sprayed using cerium reagent, while the other parts were covered with glass during the isolate taking is monitored using a $\mathrm{UV}_{254}$. The produced powder of scrapping was diluted using chloroform solvent, stirred using magnetic stirrer, and then, filtered using vacuum filter. The result of the filtration was evaporated to get dry isolate filtrate; it was then measured and tested for its antioxidant activity.

\section{Testing of purity}

$T L C$

The isolate was eluted using three mobile phases which have different polarities. When the three phases showed one spot, the compound was considered pure based on TLC.

Testing of antioxidant activity of DPPH extract, fraction, and isolate using spectrophotometry

The test was performed following the stages: Some sample was added with $1.0 \mathrm{ml}$ DPPH $0.4 \mathrm{mM}$ and $3.950 \mathrm{ml}$ methanol. The mixture was then vortexed and left for $30 \mathrm{~min}$. Its absorbance was measured at 515 $\mathrm{nm}$ wavelength using methanol. The measurement was performed for $1.0 \mathrm{ml} \mathrm{DPPH}$ and $4.0 \mathrm{ml}$ methanol. Vitamin $\mathrm{C}$ was used as the comparative compound. The percentage of free radical scavenging of the samples was calculated using the following formula [10].

Percentage [\%] of free radicals DPPH scavenging $=\frac{\mathrm{A}_{0}-\mathrm{A}_{1}}{\mathrm{~A}_{0}} \times 100 \%$

Remark:

$\mathrm{A}_{0}$ : Control absorbance (not containing sample)

$A_{1}$ : Testing sample absorbance or comparative compound.

The parameter used was $\mathrm{IC}_{50}$, the concentration of testing compound required for scavenging $50 \%$ free radicals $\mathrm{DPPH}$. The value of $\mathrm{IC}_{50}$ was obtained by designing regression linear equation stating the correlation of testing compound content and the percentage of antioxidant activity of free radicals DPPH. The lower the $\mathrm{IC}_{50}$ value, the stronger the testing compound of antioxidant.

\section{RESULT AND DISCUSSION}

Preparasi sampel sample preparation

The sample used in the study was the peel of red dragon fruit (H. polyrhizus [F.A.C.Weber] Britton dan Rose). It was $30.29 \mathrm{~kg}$ of the fruit used, and $6.79 \mathrm{~kg}$ or $23.683 \%$ peel was obtained.

\section{Extraction}

Extraction was performed through maceration using methanol; the condensed extract was partitioned using petroleum ether. It resulted in soluble and insoluble petroleum ether fractions.

\section{Testing of antioxidant activity of partition result using DPPH}

Fig. 1 and Table 1 showed the test result of DPPH method using Vitamin $\mathrm{C}$ as positive control.

\section{Fractionation using VLC column}

Regarding the antioxidant activity testing of soluble petroleum ether, the highest value of $\mathrm{IC}_{50}$ was $3.84 \mu \mathrm{g} / \mathrm{mL}$. Using VLC, it was found that soluble petroleum ether fraction had better antioxidant activity than the insoluble petroleum ether had. The static phase used was silica gel 60 for column chromatography with decreasing polarity gradient of the mobile phase. The mobile phase used was petroleum ether:ethyl acetate [50 ml PE], [49:1], [47,5:2,5], [45:5], [42,5:7,5], [40:10], [37,5:12,5], [35:15], [30:20], and [25:25]. Eluates of each solvent comparison were collected. There were 10 fractions obtained. The fractions were analyzed using TLC with promoter petroleum ether:ethyl acetate [10:1]. Then, they were sprayed with DPPH reagent and cerium sulfate.

Fig. 2 shows that fraction 4 revealed dominant spot after sprayed with cerium and positive result of DPPH indicated with yellow-whitish spots with purple background. The intensity of yellow color was the result of DPPH sprayed for antioxidant activity appearance by the compound in the spots [11].

\section{Isolation}

The active compounds found in fraction 4 were isolated using preparative TLC in static-phase silica gel $\mathrm{PF}_{254}, 0.5 \mathrm{~mm}$ of thickness, and mobile phase petroleum ether:ethyl acetate [10:1]

Table 1: $\mathrm{IC}_{50}$ value of compound testing using DPPH method

\begin{tabular}{ll}
\hline Samples & IC $_{\mathbf{5 0}}(\boldsymbol{\mu g} / \mathbf{m L})$ \\
\hline Vitamin C & 2.34 \\
Soluble petroleum ether & 3.84 \\
Insoluble petroleum ether & 12.14 \\
\hline
\end{tabular}

DPPH: 2,2-diphenyl-1-picrylhydrazyl

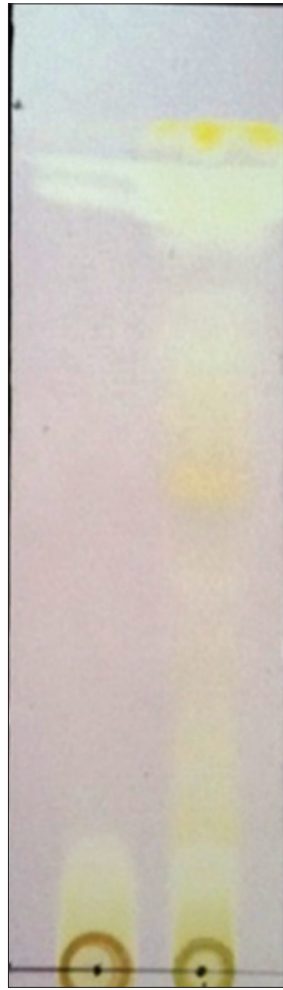

Fig. 1: Chromatogram result of soluble and insoluble petroleum ether fractions using wasbenzen:ethyl acetate (4:1). (a) Soluble petroleum ether, (b) insoluble petroleum ether

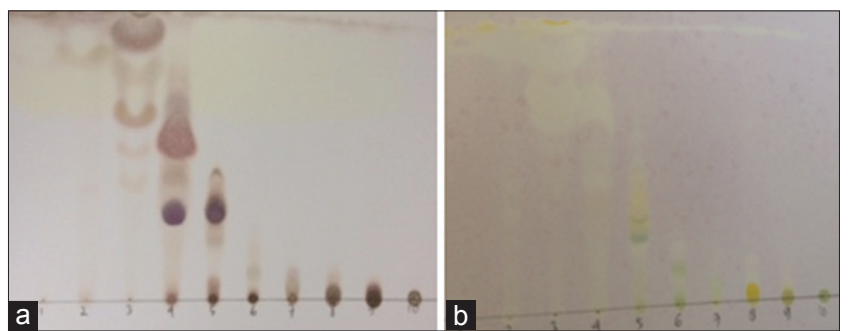

Fig. 2: Chromatogram result of vacuum liquid chromatography using petroleum ether:ethyl acetate (10:1) sprayed with cerium (a) and DPPH (b) 
Fig. 3 revealed that 2 ribbons were obtained. The tracks were scrapped, and the resulted powder was diluted in chloroform solvent, stirred using magnetic stirrer, and filtered using vacuum filter. The filtration result was evaporated to get dry isolate (filtrate).

\section{Testing of isolate antioxidant activity using DPPH method}

The result of the test with Vitamin $\mathrm{C}$ as positive control is shown in Fig. 4 and Table 2.

The obtained isolates were considered as triterpenoid compound as shown in the result of phytochemical screening of the two isolates. Phytochemical screening was performed through test tube and TLC. The resulted spots were positively terpenoids, proven LiebermannBurchard test. The screening results were shown in Table 3 and Fig. 5.

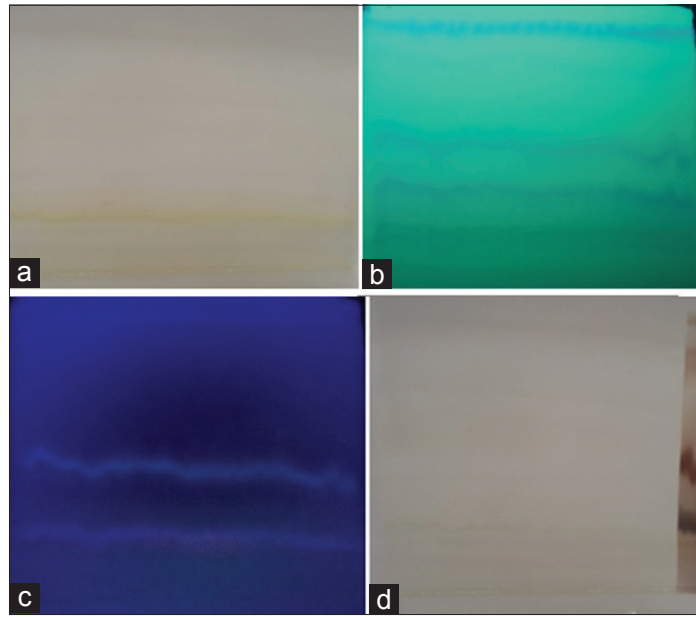

Fig. 3: Chromatogram result of preparative thin layer chromatography using petroleum ether:ethyl acetate (10:1). (a) Clear light, (b) UV 254 light, (c) UV 366 light, (d) cerium spray

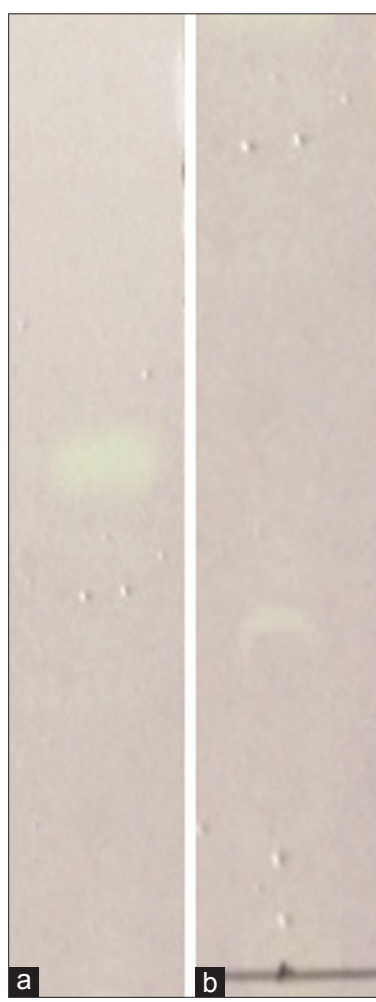

Fig. 4: Chromatogram of isolate 1 (a) and isolate 2 (b) using mobile phase petroleum ether:ethyl acetate (12:1)
Both visual and UV light observations did not reveal spots of the isolates. The detected triterpenoids were assumed to have unconjugated double bonds. As a result, triterpenoid has weak UV light absorbance ribbon. It was revealed in the result of UV spectrophotometer of isolate 1 with $\lambda_{\max } 292.2$ and isolate 2 with $\chi_{\max } 279.0$ (Fig. 6).

Table 2: $\mathrm{IC}_{50}$ value of isolate using DPPH method

\begin{tabular}{ll}
\hline Samples & IC $_{\mathbf{5 0}}(\boldsymbol{\mu g} / \mathbf{m L})$ \\
\hline Vitamin C & 2.34 \\
Isolate 1 & $2,952.14$ \\
Isolate 2 & $25,635.95$ \\
\hline DPPH: 2 2-diphenyl-1-picrylhydrazyl
\end{tabular}

DPPH: 2,2-diphenyl-1-picrylhydrazyl

Table 3: Phytochemical screening result of fraction 4 of red dragon fruit peel

\begin{tabular}{|c|c|c|c|}
\hline Treatments & Testing methods & $\begin{array}{l}\text { Theoretical } \\
\text { positive results }\end{array}$ & $\begin{array}{l}\text { Observation } \\
\text { results }\end{array}$ \\
\hline \multirow[t]{2}{*}{ Alkaloid } & Mayer reagent & $\begin{array}{l}\text { White-yellowish } \\
\text { sediment }\end{array}$ & - \\
\hline & $\begin{array}{l}\text { Dragendorff } \\
\text { reagent }\end{array}$ & $\begin{array}{l}\text { Red-orange } \\
\text { sediment }\end{array}$ & - \\
\hline Flavonoid & $\begin{array}{l}\text { Willstatter } \\
\text { cyanidin testing }\end{array}$ & $\begin{array}{l}\text { Red-orange; } \\
\text { dark red; green- } \\
\text { blue sediment }\end{array}$ & - \\
\hline Triterpenoid & Liebermann- & Red/ring red & + \\
\hline Steroid & Burchard testing & Blue or purple & + \\
\hline Saponin & Forth testing & $\begin{array}{l}\text { Stable foam for } \\
10 \mathrm{~min}\end{array}$ & - \\
\hline Fenolic & $+\mathrm{FeCl}_{3} 1 \%$ & $\begin{array}{l}\text { Purple, blue, } \\
\text { and dark green }\end{array}$ & - \\
\hline Tanin & $\begin{array}{l}+\mathrm{NaCl} 10 \% \text { and } \\
\mathrm{FeCl}_{3} 1 \%\end{array}$ & Dark blue & - \\
\hline
\end{tabular}

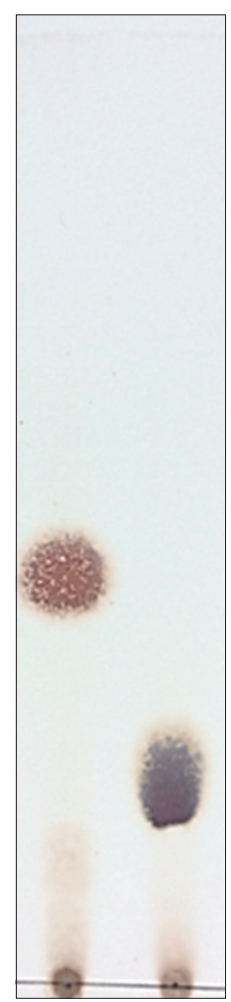

Fig. 5. Chromatogram of isolate 1 and 2 using lieberman-burchard reagent spray 


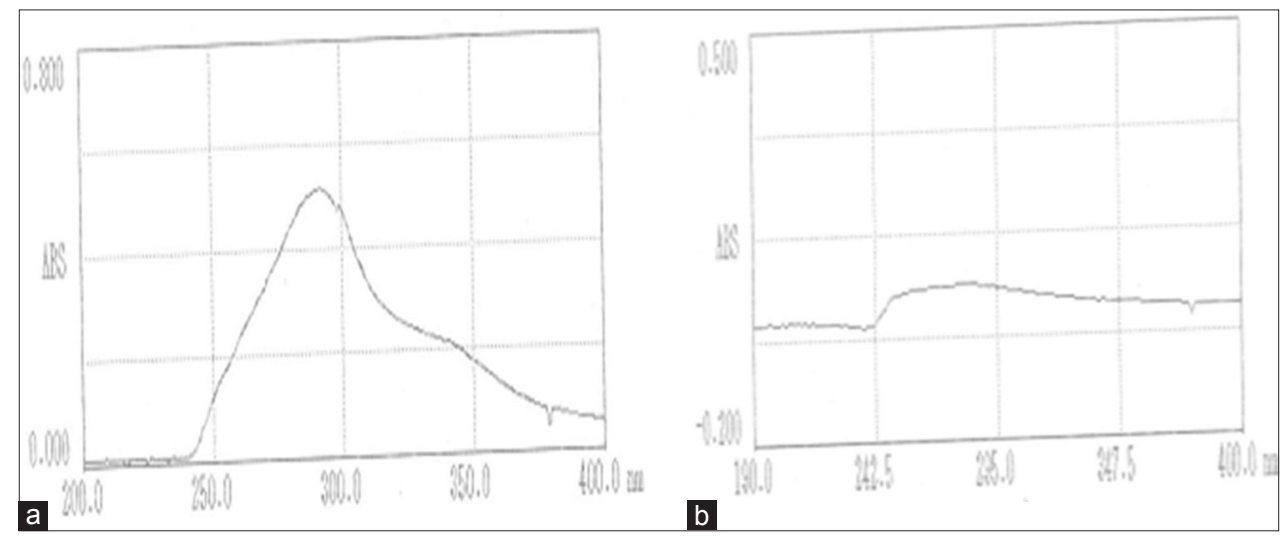

Fig. 6: Results of UV spectrophotometer of isolate 1 (a) and isolate 2 (b)

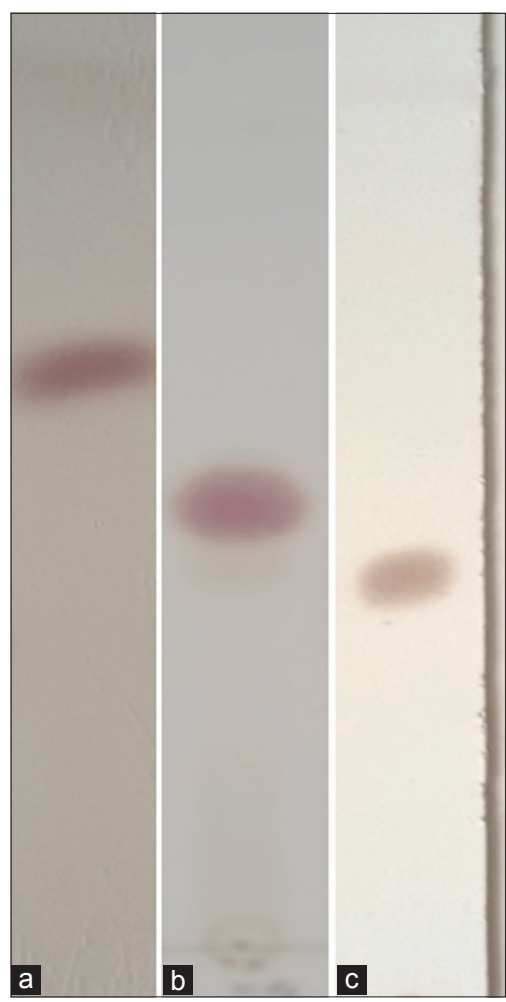

Fig. 7: Chromatogram of purity testing of isolate 1 using mobile phases petroleum ether:ethyl acetate (10:1) (a), petroleum ether:ethyl acetate (20:1) (b), $n$ - hexane:ethyl acetate (30:1) (c)

Testing of isolate antioxidant activity of the fruit peel using DPPH was performed at the maximum wavelength of $516.0 \mathrm{~nm}$. Based on the observation result, the isolate of the peel which was reacted with DPPH after 30-min incubation did not reveal significant changes. The change of color from purple to pale yellow indicates the existence of antioxidant activity [12]. Terpenoid compound do not have any hydroxyl structure so that it cannot donate hydrogen atom to reduce DPPH molecule followed by the disappearing purple of DPPH. From existing data, Table 2 showed that the isolates 1 and 2 are a compound with the DPPH radical-catcher nature which are very weak when compared with the control of Vitamin C.

\section{Testing of isolate purity using TLC}

Isolates 1 and 2 were eluted using three kinds of phases which different polarities. The mobile phases used for isolate 1 were PE:ethyl acetate

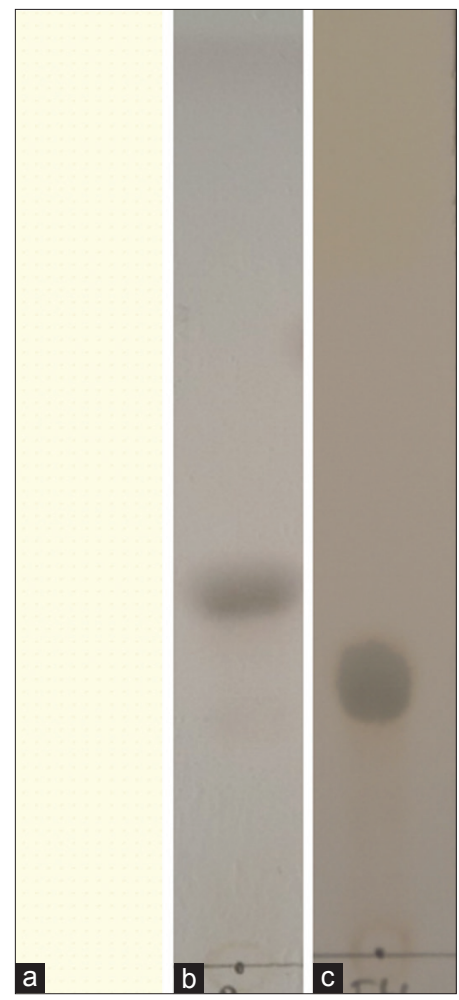

Fig. 8: Chromatogram of purity testing of isolate 2 using mobile phases chloroform $100 \%$ (a), petroleum ether:ethyl acetate $(10: 1)(b)$, petroleum ether:ethyl acetate $(12: 1)(c)$

[10:1], PE:ethyl acetate [20:1], n-hexane:ethyl acetate [30:1], while the phases used for isolate 2 were PE:ethyl acetate [10:1], chloroform 100\%, and PE:ethyl acetate [12:1]. The results showed 1 spot of all TLC test performed so that the isolates were said to be pure. The results were shown in Figs. 7 and 8.

\section{CONCLUSION}

In accordance with the results of the study, it is concluded that isolate of dragon fruit has antioxidant activity. The compound which results in antioxidant activity is terpenoid.

\section{CONFLICTS ON INTEREST STATEMENT}

There is no conflict of interest. 


\section{REFERENCES}

1. Omidizadeh A, Yusof RM, Ismail A, Roohinejad S, Nateghi L Bakar MZ. Cardioprotective compounds of red pitaya (Hylocereus lemairei) fruit. J Food Agric Environ 2011;9:152-6.

2. Jamilah B, Shu CE, Kharidah M, Dzulkifly MA, Noranizan A. Physicochemical characteristics of red pitaya (Hylocereus lemairei) peel. Int Food Res J 2011;18:279-86.

3. Wu L, Hsu HW, Chen YC, Chiu CC, Lin YI, Ho JA. Antioxidant and antiproliferative activities of red pitaya. Food Chem 2006;95:319-27.

4. Nurliyana R, Syed ZI, Mustapha SK, Aisyah MR, Kamarul RK. Antioxidant study of pulp and peel dragon fruits: A comparative study. Int Food Res J 2010;17:365-75.

5. Wahdaningsih S, Wahyuono S, Riyanto S, Murwanti R. The radical scavenging activity of 2-2' diphenyl-1- picrylhydrazil (dpph) on the methanol extracts and ethyl acetate fractions of red dragon fruit peel (Hylocereus polyrhizus (F.A.C.Weber) Britton dan Rose). Int J Phytomed 2017;9:79-82.

6. Pham-Huy LA, He H, Pham-Huy C. Free radicals, antioxidants in disease and health. Int J Biomed Sci 2008;4:89-96.

7. Sunarni T, Pramono S, Asmah R. Antioxidant free radical scavenging of flavonoid from the leaves of Stelechocarpus burahol (B1. Hook f. and $\mathrm{Th}$ ). leaves on the body weight and organ of sparague-dawley rats. Indones J Pharm 2007;18:111-6.

8. Thenmozhi K, Karthika K, Jamuna S, Paulsamy S, Manian S, Chitravadivu C. In vitro antioxidant and radical scavenging abilities of aqueous methanolic extract of Cassia obtosa L. plant parts (Caesalpiniaceae). Int J Pharm Pharm Sci 2015;7:340-4.

9. Mohammad SN, Srinivasulu A, Chitibabu B, Rao MU. Isolation and purification of antibacterial principle from Avicennia marina $\mathrm{L}$ in methanol. Int J Pharm Pharm Sci 2015;7:38-41.

10. Kikuzaki $\mathrm{H}$, Hisamoto $M$, Hirose $\mathrm{K}$, Akiyama $\mathrm{K}$, Taniguchi $\mathrm{H}$. Antioxidant properties of ferulic acid and its related compounds. J Agric Food Chem 2002;50:2161-8.

11. Demirezer LO, Kuruüzüm-Uz A, Bergere I, Schiewe HJ, Zeeck A. The structures of antioxidant and cytotoxic agents from natural source: anthraquinones and tannins from roots of Rumex patientia. Phytochemistry 2001;58:1213-7.

12. Molyneux P. The use of the stable free radical diphenyl picrylhydrazyl (DPPH) for estimating antioxidant activity. Songklanakarin J Sci Technol 2004;26:211-9. 